\title{
A new record of the rare fungus Peziza saniosa (Pezizales, Ascomycota) in Ukraine
}

\author{
Veronika V. DZHAGAN ${ }^{1}$, Yulia V. SHCHERBAKOVA², Anastasia I. SNIEZHYK ${ }^{1}$ \\ ${ }^{1}$ Taras Shevchenko National University of Kyiv \\ 64/13 Volodymyrska Str., Kyiv 01601, Ukraine \\ veronika.dzhagan@gmail.com \\ ${ }^{2}$ State Scientific Research Expert-Forensic Centre of the Ministry of Internal Affairs of Ukraine \\ 10 Bohomoltsa Str., Kyiv 01024, Ukraine \\ yulia.shcherbakova@ukr.net
}

Dzhagan V.V., Shcherbakova Yu.V., Sniezhyk A.I. 2020. A new record of the rare fungus Peziza saniosa (Pezizales, Ascomycota) in Ukraine. Ukrainian Botanical Journal, 77(3): 204-209.

Abstract. A new locality of a rare species, Peziza saniosa (Pezizales, Ascomycota), is reported in Ukraine. The fungus was found in August 2016 in the Uholsko-Shyrokoluzhanskyi Mountain Range of Carpathian Biosphere Reserve (Transcarpathian Region, Ukraine). Earlier P. saniosa was registered in Ukraine only once, more than a hundred years ago in Ternopil Region. Thus, the current record from the Ukrainian Carpathians is the second one for Ukraine. A brief description of the species, information on its general distribution, and original illustrations are provided.

Keywords: biodiversity, Carpathian Biosphere Reserve, distribution, morphology, Peziza

Submitted 03 March 2020. Published 30 June 2020

Джаган В.В. ${ }^{1}$, Щербакова Ю.В. ${ }^{2}$, Снєжик А.І. ${ }^{1}$ 2020. Нова знахідка рідкісного гриба Peziza saniosa (Pezizales, Ascomycota) в Україні. Украӥнський ботанічний журнал, 77(3): 204-209.

${ }^{1}$ Київський національний університет імені Тараса Шевченка вул. Володимирська 64/13, Київ 01601, Україна

2 Державний науково-дослідний експертно-криміналістичний центр МВС України вул. Богомольця 10, Київ 01014, Україна

Реферат. Повідомляється про знахідку в Україні рідкісного дискоміцета Peziza saniosa (Pezizales, Ascomycota). Гриб був знайдений у серпні 2016 року в Угольсько-Широколужанському масиві Карпатського біосферного заповідника (Закарпатська область, Україна). До цього P. saniosa був виявлений на території України лише один раз понад сто років тому в Тернопільській області. Таким чином, знахідка даного виду з Українських Карпат є другою для України. Подано короткий опис, інформацію щодо загального поширення та оригінальні ілюстрації цього виду.

Ключові слова: Peziza, дискоміцети, Карпатський біосферний заповідник, морфологія, поширення

\section{Introduction}

During a field trip to Carpathian Biosphere Reserve (Transcarpathian Region, Ukraine) in 2016, the second author of the present article found ascomata of an interesting fungus Peziza saniosa Schrad. ex J.F. Gmel. (Pezizales, Ascomycota). This operculate discomycete is known to occur in the Northern Hemisphere (Europe,
North America) as well as in Asia and Australasia (Barseghyan, Wasser, 2011). Despite its wide general distribution, the species has been rarely recorded throughout its range, and thus in most countries it is considered to be a rare or at least uncommon fungus. In Ukraine P. saniosa was first found in 1905 in Ternopil Region (Bobjak, 1907). Since that record, the species has not been reported again in Ukraine.

(C) 2020 V.V. Dzhagan, Yu.V. Shcherbakova, A.I. Sniezhyk. Published by the M.G. Kholodny Institute of Botany, NAS of Ukraine. This is an open access article under the terms of the Creative Commons Attribution License (http://creativecommons.org/licenses/by/4.0/), which permits use, distribution, and reproduction in any medium, provided the original work is properly cited 
Peziza Dill. ex Fr. is a large genus comprising approximately 112 confirmed taxa (Jaklitsch et al., 2016), with numerous synonymic names due to placement of some species in other genera. In the genus Peziza, it is sometimes hard to find reliable diagnostic characters of different species. One of the reasons is the lack of certain critical characters of apothecia, such as the hymenium and outer surface colour, production of coloured juice, etc., due to insufficient study of fresh material. The main morphological character of $P$. saniosa distinguishing it from other species of the genus is excretion of blue-violet or bluish coloured latex that appears in case of damage to the hymenial layer of the ascomata (Fig. 1). This kind of latex is not peculiar to the majority of other species of Peziza (Moser, 1963; Dennis, 1978; Breitenbach, Kränzlin, 1984; Moreno, Remondo, 2003). Thereby, this fungus can be easily recognized when the fresh material is available.

It should be noted that we have preliminarily reported this species (based on the same sample as presented here) in the list of fungal species in the recently published book Fungi of Reserves and National Nature Parks of the Ukrainian Carpathians (Dudka et al., 2019). However, in this article we provide a detailed description with the main diagnostic features, updated information about the general range, precise data on the locality in Ukraine, habitat, and original illustrations of the specimen of P. saniosa found in Ukraine (Figs 1-2).

\section{Materials and Methods}

The fungus was collected in August 2016 during a field survey in Carpathian Biosphere Reserve (Transcarpathian Region, Ukraine). Macroscopic description of the collected specimen is based on fresh ascomata. Microscopic features are described from dried material mounted in tap water $\left(\mathrm{H}_{2} \mathrm{O}\right), 3 \% \mathrm{KOH}$, Congo Red solution (CR), Melzer's reagent (MLZ), IKI (iodinepotassium iodide) and Lactophenol Cotton Blue (LPCB), using an XY-B2T light microscope (Ulab, China) and a Primo Star light microscope (Carl Zeiss, Germany). Digital photomicrographs were made with a ScienceLab DCM 520 digital camera with Tsview 7 modular software (Fuzhou Tucsen Imaging Technology Co., Ltd., Fuzhou, Fujian, China).

Analysis of fungus' general distribution is based on the data from bibliographic sources listed in References and on critically revised open online resources, as well as the Global Biodiversity Information Facility (GBIF, http:/ www.gbif.org/). The collected specimen is deposited in the Herbarium of the Taras Shevchenko National University of Kyiv (KWHU).

\section{Results and Discussion}

Since the diagnosis of the species is provided by many available and easily accessible resources, we restrict our report to a brief description of morphological features of $P$. saniosa based only on the specimen recently collected in Ukraine.

Peziza saniosa Schrad. ex J.F. Gmel., Systema Naturae 2(2): 1459 (1792). - Syn.: Aleuria saniosa (Schrad. ex J.F.Gmel.) Gillet, Champignons de France, les Discomycètes: 46 (1879). - Galactinia saniosa (Schrad. ex J.F.Gmel.) Sacc., Sylloge Fungorum 8: 106 (1889). - Plicaria saniosa (Schrad. ex J.F.Gmel.) Rehm, Rabenhorst's Kryptogamen-Flora, Pilze - Ascomyceten 1(3): 1004 (1894).

Apothecia discoid, about 1-1.5 (up to 2) $\mathrm{cm}$ in diameter. Hymenium smooth, from dark violet to dark brownish, almost black in old specimens, dark brown outside [some authors (Moser, 1963; Dennis, 1978) state the colour of the outer surface as being dark grayish brown or dark purple]. When hymenium is injured, bluish juice turning violaceous appears on the hymenial surface (Fig. 1). Medullary excipulum predominantly of textura globulosa, cells up to $60 \mu \mathrm{m}$ in diameter, thin-walled. Ectal excipulum of textura globulosa, cells 19.0-42.5 $\mu \mathrm{m}$ in diameter, with gelled walls, intermixed with hyphae. Asci $360-400 \times 14-15 \mu \mathrm{m}$, operculate, cylindrical, 8-spored, apex truncate-rounded, reacting positively with Melzer's reagent and IKI, turning blue at the apex (Fig. 2, A, B1-B2). Ascospores narrowly ellipsoid, slightly narrowed at the poles, $15.5-16.2 \times 7.5-8.2 \mu \mathrm{m}$, uniseriate, hyaline, with two large guttules, sculpturing consists of small warts to extended ridges (Fig. 2, C1C5). Paraphyses straight, cylindrical, simple, wider at the apex.

Habitat. Humus saprotroph. On wet soil, along the stream in a beech (Fagus sylvatica) forest.

Specimen examined. Ukraine, Transcarpathian Region, Tyachiv District, Uholsko-Shyrokoluzhanskyi Mountain Range of Carpathian Biosphere Reserve, Mala Uholka, 48.257523 N, 23.632278 E, 13 August 2016, leg. Yulia Scherbakova (KWHU 161308).

General distribution. Europe: Austria, Belgium, Bosnia and Herzegovina, Bulgaria, Czech Republic, Denmark, Finland, France, Germany, Italy, Netherlands, 


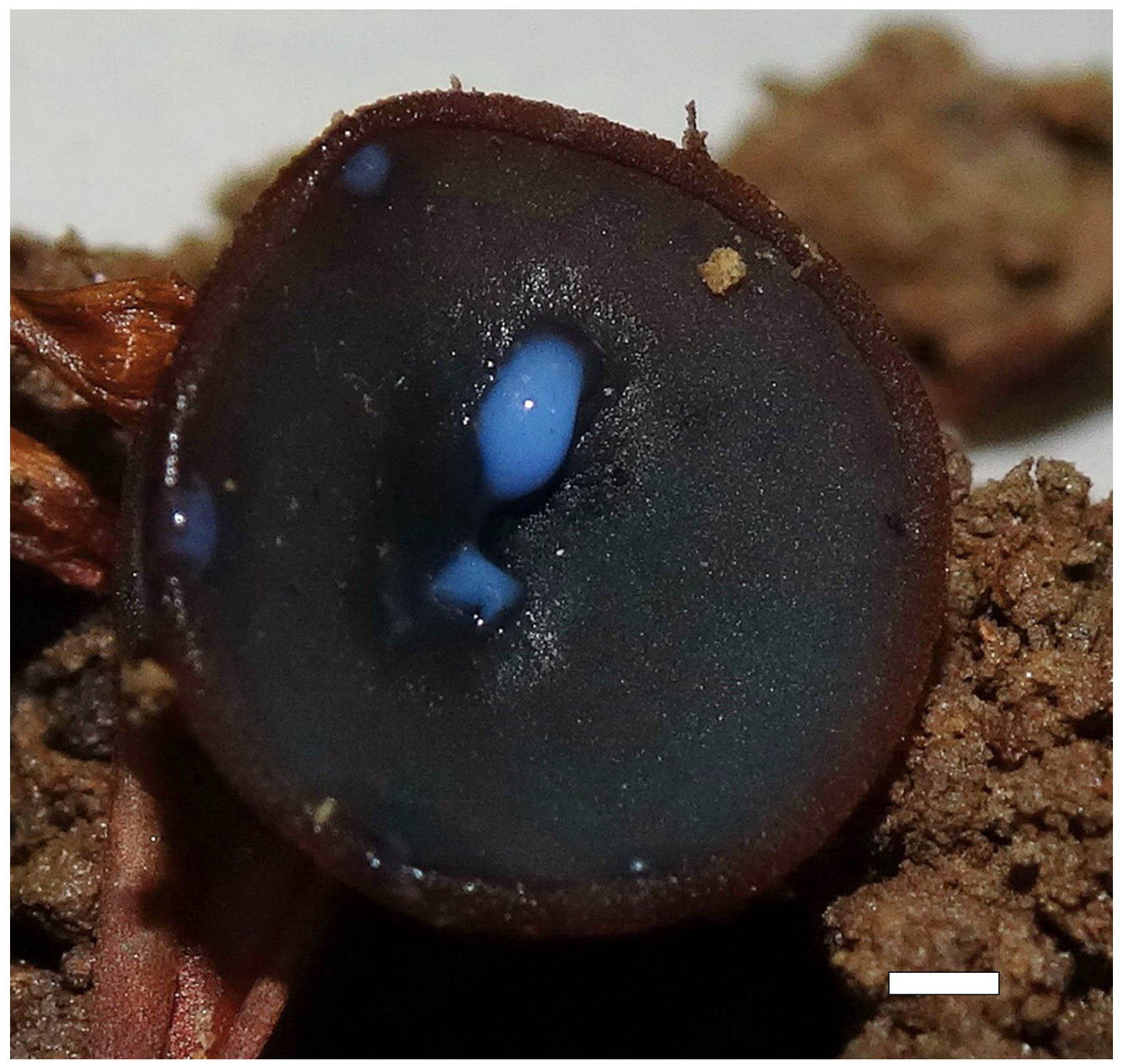

Fig. 1. Peziza saniosa. Fresh apothecium with blue latex. Scale bar: $2 \mathrm{~mm}$

Norway, Poland, Romania, Russia, Serbia, Slovakia, Slovenia, Spain [including Canary Islands (Tenerife) and Balearic Islands (Mallorca)], Sweden, Switzerland, Ukraine, United Kingdom; Asia: Israel, China, Turkey; North America: Mexico, USA; Africa: Morocco; Australasia: New Zealand (Tabarés, Rocabruna, 1991; Zotti, Orsino, 2001; Moreno, Remondo, 2003; Tănase, Pop, 2005; Ribes, 2009; Pancorbo, Ribes, 2010; Barseghyan, Wasser, 2011; Mihál et al., 2011; Ciortan, 2013; Kholfy et al., 2014; Akata, Uzin, 2017; Gierczyk et al., 2018; Savić et al., 2018; Jukić et al., 2019; GBIF, http:/www.gbif.org/).

Peziza saniosa is considered to be a rare species occurring in broad-leaved forests, particularly those formed by beech and oak-hornbeam stands, also in coniferous forests, among mosses, on grassy and bare ground, on leaf or needle litter, rotting wood, usually from late spring to mid-autumn.

It is listed in the preliminary European Red List of the European Council for the Conservation of Fungi (http:// 


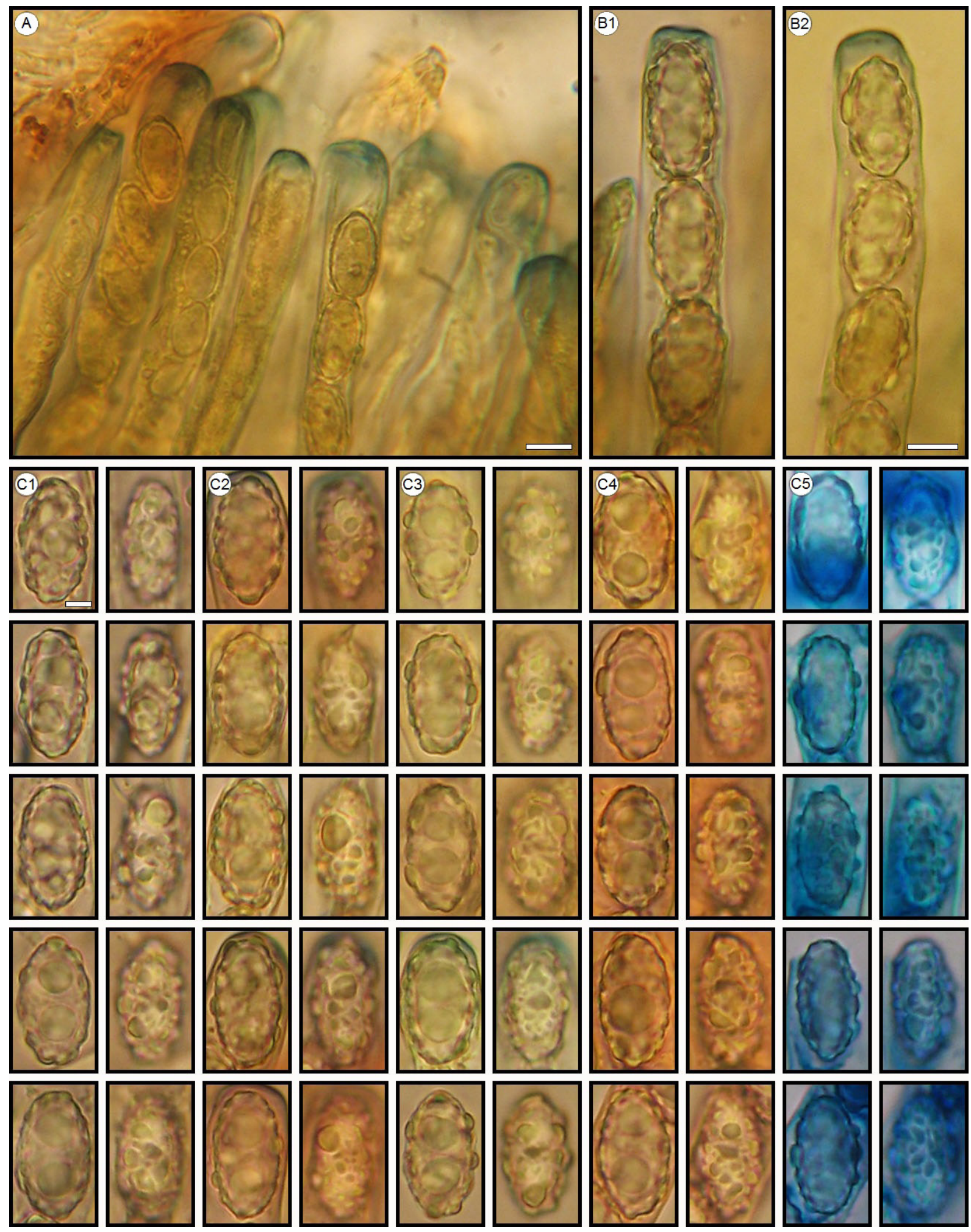

Fig. 2. Peziza saniosa. A: fragment of hymenial layer (IKI+); B1-B2: fragment of asci with ascospores (MLZ+); C1-C5: mature ascospores in different types of media (C1-H $\mathrm{H}_{2}$; C2 - IKI; C3 - MLZ; C4 - CR; C5 - LPCB). Bars: $10 \mu \mathrm{m}$ (A, B1-B2); $5 \mu \mathrm{m}$ (C1-C5) 
www.wsl.ch/eccf/candlist-subtotals.xls) and is protected under various categories in some countries, such as the Czech Republic (Critically Endangered, CR), Finland and France (Endangered, EN), Germany (Vulnerable, VU), Norway and Sweden (Near Threatened, NT). In the Red List of Romanian Macrofungi, P. saniosa is considered as very rare and has the Near Threatened (NT) status (Tănase, Pop, 2005). In the Red List of Fungi in Bulgaria the fungus is categorized as Vulnerable (VU) (Gyosheva et al., 2006), while in Poland it is classified as rare or potentially Endangered species (Kujawa et al., 2016).

Although it is red-listed as a threatened species in several European countries and most authors describe this species as rare, the number of its finds has increased over the last years (Ševčíková, 2017). Only in the Czech Republic, 45 localities of the fungus have been recorded since 2006 (Egertová, 2015). Considering that $P$. saniosa is a thermophilic species, it may be due to mild winters and hot summers that were predominant during recent years.

At the same time, in Bosnia and Herzegovina it is a quite common and widespread species, inhabiting various types of habitats. Thus, in this country $P$. saniosa is recommended to be evaluated as a Least Concern (LC) species (Jukić et al., 2019).

In Ukraine, our collection from the Ukrainian Carpathians is the second record of $P$. saniosa in the country. The first find, from vicinity of the town of Berezhany, Ternopil Region, was reported by Bobjak (1907) more than a hundred years ago. Therefore, we can assume that $P$. saniosa is a rare species in Ukraine. For better understanding of its distribution, conservation status and possibility of including the species in the Red Data Book of Ukraine, further observations in the Carpathians and in Ukraine in general are required.

\section{References}

Akata I., Uzin Y. 2017. Macrofungi determined in Uzungöl Nature Park (Trabzon). Trakya University Journal of Natural Sciences, 18(1): 15-24. https://doi.org/10.23902/ trkjnat.295542

Barseghyan G.S., Wasser S.P. 2011. The genus Peziza Dill. ex Fr. (Pezizales, Ascomycota) in Israel. Ascomycete.org, 2(4): 39-50.

Bobjak H. 1907. Symbolae ad Mycologiam Haliciae orientalis. Fungi agri Berežanensis. Sammelschrift der Mathematisch-naturwissenschaftlich-ärztlichen Sektion der Ševčenko-Gesellschaft der Wissenschaften in Lemberg, 11: 1-41. [Бобяк Г. 1907. Причинки до мікології східної Галичини. Гриби околиці Бережан. Збірник Математично-природописно-лікарської секції Наукового Товариства імені Шевченка, 11: 1-41].

Breitenbach J., Kränzlin F. 1984. Fungi of Switzerland, vol. 1. Ascomycetes. $2^{\text {nd }}$ ed. Lucerne: Mykologia, $310 \mathrm{pp}$.

Ciortan I. 2013. The taxonomic diversity of the macromycetes from Căpăţânii mountains (Romania). Journal of Horticulture, Forestry and Biotechnology, 17(1): 41-50.

Dennis R.W.G. 1978. British Ascomycetes. $2^{\text {nd }}$ ed. Vaduz: J. Cramer, 486 pp.

Dudka I.O., Heluta V.P., Prydiuk M.P., Tykhonenko Yu.Ya., Akulov O.Yu., Hayova V.P., Zykova M.O., Andrianova T.V., Dzhagan V.V., Shcherbakova Yu.V. 2019. Fungi of Reserves and National Nature Parks of the Ukrainian Carpathians. Ed. V.P. Heluta. Kyiv: Naukova Dumka, 215 pp. [Дудка I.O., Гелюта В.П., Придюк М.П., Тихоненко Ю.Я., Акулов О.Ю., Гайова В.П., Зикова М.О., Андріанова Т.В., Джаган В.В., Щербакова Ю.В. 2019. Гриби заповідників і начіональних природних парків Украӥнських Карпат. Ред. В.П. Гелюта. Київ: Наукова думка, 215 с.].

Egertová Z. 2015. New finds of Peziza saniosa in the Czech Republic. Mykologické listy, Praha, 131: 1-9.

Gierczyk B., Ślusarczyk T., Szczepkowski A., Kujawa A. 2018. $23^{\text {th }}$ exhibition of Fungi of the Białowieża Forest. Materials to the knowledge of mycobiota of the Białowieża Primeval Forest. Przeglad Przyrodniczy, 29: 9-57.

Gyosheva M.M., Denchev C.M., Dimitrova E.G., Assyov B., Petrova R.D., Stoichev G.T. 2006. Red list of fungi in Bulgaria. Mycologia Balcanica, 3: 81-87.

Jaklitsch W., Baral H.O., Lücking R., Lumbsch H.T. 2016. Syllabus of Plant Families - A. Engler's Syllabus der Pflanzenfamilien, vol. 1, part 2: Ascomycota. Borntraeger: Stuttgart, $322 \mathrm{p}$.

Jukić N., Matočec N., Kušan I., Gašić R., Omerović N., Tomić S. 2019. Diversity of Ascomycetous fungi in the territories of protected areas and in the areas evaluated for the protection in Bosnia-Herzegovina: establishing important fungus areas (IFA). Sarajevo: Mycological Society MycoBH, 234 pp.

Kholfy S.E., Outcoumit A., Touhami A.O., Belahbib N., Benkirane R., Douira A. 2014. Bibliographic inventory of Tangier's fungi: catalogue of the Ascomycetes fungal flora. International Journal of Plant, Animal and Environmental Sciences, 4(3): 77-92.

Kujawa A., Szczepkowski A., Gierczyk B., Ślusarczyk T., Chachuła P., Karasiński D. 2016. Grzyby wielkoowocnikowe w Bieszczadzkim Parku Narodowym. In: Bieszczadzki Park Narodowy - 40 lat ochrony. Eds A. Górecki, B. Zemanek, Bieszczadzki Park Narodowy, pp. 199-210.

Mihál I., Glejdura S., Blanár D. 2011. Macromycetes (Zygomycota, Ascomycota, Basidiomycota) in the massif of the Kohút Mountain (the Stolické vrchy Mts). Reussia, 6(1-2): 1-44.

Moreno A.C., Remondo J.P. 2003. Aportación al catálogo micológico de la Rioja (Espaňa): el género Peziza Linneo ex Amans. Zubia, 21: 9-27. 
Moser M.M. 1963. Ascomyceten (Schlauchpilze). Kleine Kryptogamenflora IIa. Stuttgart, Gustav Fischer, 147 pp.

Pancorbo F., Ribes M.A. 2010. Mediterranean dune fungi. Boletín de la Sociedad Micológica de Madrid, 34: 271-294.

Ribes M.A. 2009. Contribution to the mycobiota knowledge from Canary Islands (Spain) I. Boletín de la Sociedad Micológica de Madrid, 33: 201-223.

Savić D., Kajevska I., Milosavljević N. 2018. Checklist of Pezizomycetes from Serbia. Bulletin of the Natural History Museum in Belgrade [Glasnik Prirodnjačkog muzeja u Beogradu], 11: 21-61. https://doi.org/10.5937/ bnhmb1811021S
Ševčíková H. 2017. Zajímavé makromycety př́írodní rezervace Zadní Hády. Mykologický sborník, 1: 7-21.

Tabarés M., Rocabruna A. 1991. Aportación al conocimiento de los hongos de la Sierra de Collserola y zonas próximas (Catalunya). II. Revista Catalana de Micologia, 14-15: 87-97.

Tănase C., Pop A. 2005. Red list of Romanian macrofungi species. Bioplatform - Romanian National Platform for Biodiversity. Bucureşti: Academiei Române: 101-107.

Zotti M., Orsino F. 2001. The check-list of Ligurian macrofungi. Flora Mediterranea, 11: 115-294.

Recommended for publication by V.P. Hayova 